UDC 577.25, 591.87, 611.44

\title{
Colocalization of cortactin and PH domain of BCR in HEK293T cells and its potential role in cell signaling
}

\author{
D. S. Gurianov ${ }^{1}$, S. V. Antonenko, G. D. Telegeev ${ }^{1}$ \\ ${ }^{1}$ Institute of Molecular Biology and Genetics, NAS of Ukraine \\ 150, Akademika Zabolotnoho Str., Kyiv, Ukraine, 03680
}

\begin{abstract}
Chromosomal translocation $\mathrm{t}(9 ; 22)(\mathrm{q} 34 ; \mathrm{q} 11)$ leads to generation of different types of the BCR-ABL fusion protein and cause different types of leukemia. The generated fusion proteins differ by the presence or absence of certain domains of $\mathrm{BCR}-\mathrm{C} 2, \mathrm{PH}$, and $\mathrm{DH}$. Mass-spectrometric analysis identified 23 possible interaction partners of $\mathrm{PH}$ domain of BCR. Among them is cortactin (CTTN), which is a multidomain protein responsible for the actin branching during endocytosis. The activation of cortactin occurs after phosphorylation by SRC kinase. However, it is unknown whether ABL kinase can phosphorylate and activate CTTN in the same manner. Aim. To demonstrate whether CTTN and PH domains of BCR colocalize in HEK293T cells, to analyze possible phosphorylation sites for the ABL kinase in the cortactin and to make a comparative prediction for SRC kinase. Methods. HEK293T cells were transfected with the engineered pECFP-C3-CTTN and pmCitrine-C1-PH using a cationic polymer transfection and evaluated with fluorescent microscopy. Putative phosphorylation sites of CTTN by ABL and SRC kinases were predicted by GPS 2.1 software. Results. PH domain and CTTN were expressed in HEK293T cells and show specific cellular colocalization. Phoshorylation sites for ABL kinase (Y384, Y396, Y409, Y416, Y427, Y433, and Y449) were detected in the proline-rich region of CTTN; they match the corresponding sites predicted for SRC kinase. Conclusions. We have shown that CTTN has a cytoplasmic localization; PH domain of BCR was localized predominantly but not exclusively in the nucleus. Their partial colocalization occurs in specific dot-like perinuclear regions. A potential phosphorylation of CTTN by ABL may be one of the activation pathways during leukemogenesis.
\end{abstract}

Key w or d s: CML, BCR-ABL, PH domain, CTTN.

\section{Introduction}

Philadelphia chromosome is a distinct marker of several leukemia types. It is a result of $\mathrm{t}(9 ; 22)$ (q34;q11) reciprocal chromosomal translocation, which leads to the fusion of $b c r$ and $a b l$ genes [1]. The resulting chimeric protein BCR-ABL exists in three forms designated as p190, p210, and p230 according to their molecular weight. Each form is associated with different leukemias: p190 is detected in acute lymphoblastic leukemia (ALL), p210 is a marker of chronic myelogenous leukemia (CML), and p230 occurs during chronic neutrophilic leukemia $[2,3]$. The reason of such differences in length and molecular weight is the absence or presence of the functional domains of BCR protein in the fusion protein BCR-ABL due to the different chromosome breakpoints in $b c r$ gene but not in $a b l$ gene. These domains are as follows: $\mathrm{C} 2, \mathrm{Dbl}$ homology (DH) and Pleckstrine homology (PH). DH and $\mathrm{PH}$ domains are present in p210, but not in p190 form [2,4]. Consequently, these functional domains may play crucial role in cellular signaling that promotes development of either ALL or CML phenotype [5]. DH domain has Rac GTPase activity and therefore is important in the GTP-dependent cellular signaling [6,7]. From the other hand, a function of $\mathrm{PH}$ domain may vary because of its

C 2016 D. S. Gurianov et al.; Published by the Institute of Molecular Biology and Genetics, NAS of Ukraine on behalf of Biopolymers and Cell.

This is an Open Access article distributed under the terms of the Creative Commons Attribution License (http://creativecommons.org/licenses/by/4.0/), which permits unrestricted reuse, distribution, and reproduction in any medium, provided the original work is properly cited 
presence in many signaling proteins and limited sequence similarity [8]. The mainly well-studied function of PH domain is the ability to bind phosphoinositides. However this function is not the only one and predominant $[9,10]$. A function of $\mathrm{PH}$ domain of BCR is still poorly understood, as well as the function of BCR protein itself, making it a perspective research object. This domain is also important for protein-protein interactions. Previous study conducted by Miroshnychenko et al. indicated 23 potential interaction partners of $\mathrm{PH}$ domain of BCR among the cellular proteins in K562 cell line [11]. Several of those potential partners may be grouped as the regulators of cytoskeleton organization or the structural parts of cytoskeleton, like cortactin (CTTN), cytokeratin 10 (KRT10) and tubulin beta chain (TUBB). KRT10 and TUBB are the structural components of intermediate filaments and microtubules, respectively. Cortactin is a multidomain protein that provides the actin branching during the scission of clathrin-coated pits [12] and the protein transport in Golgi network $[13,14]$. It requires activation upon phoshorylation of its proline-rich region by Src kinase and interaction with Arp2/3 complex [15-17]. The previous data about the interaction of cortactin and $\mathrm{PH}$ domain of BCR were obtained by mass-spectrometry of the protein complexes after pull-down of the his-tagged $\mathrm{PH}$ domain of BCR with the proteins from K562 cell lysate [11] and need to be confirmed with more reliable methods. This will shed light on the spatial distribution of $\mathrm{PH}$ domain of $\mathrm{BCR}$ and its possible interaction partners inside the cell.

It is also important to investigate whether cortactin could be a possible target for tyrosine phosphorylation by ABL kinase, as it is for Src kinase [18].

\section{Materials and Methods}

\section{Genetic constructs}

DNA fragment corresponding to coding sequence of cortactin has been amplified from pOTB7-CTTN construction (kindly provided by Pontus Aspenstrom,
Karolinska institute, Sweden) with CTTN sense (5'-tatagaattcAGATGTGGAAAGCTTCAGCAG) and CTTN antisense (5'-tataggatccAAAGAAGGC CTGATCTGTAGTG) primers. Derived fragment was column-purified and digested with EcoRI and BamHI restriction endonucleases according to manufacturer's guide (Thermo Scientific). Digested DNA fragment was ligated to pBluescriptII SK $(+)$ vector on EcoRI and BamHI sites and to pECFP-C3 vector on corresponding sites according to manufacturer's instructions (Thermo Scientific). DNA fragment of PH domain of BCR was subcloned from pET32a-PH construction (created by D. Miroshnychenko) to pmCitrineC1 on BamHI/BglII - HindIII sites according to manufacturer's instructions (Thermo Scientific). After ligation of CTTN in pBluescriptII SK $(+)$ vector, ligase mix have been transformed to Mach1 competent E.coli cells and spread on LB agar plates containing $0.1 \mathrm{mM}$ IPTG $0.03 \% \mathrm{X}-\mathrm{Gal}$ and $50 \mathrm{ug} / \mathrm{ml}$ ampicillin and were grown at $37^{\circ} \mathrm{C}$ for $18 \mathrm{hrs}$ for blue-white screening. After ligation of CTTN to pECFP-C3 and PH domain to pmCitrine-C1 the ligase mix have been transformed to DH5 $\alpha$ E.coli competent cells, spread on LB agar plates with $50 \mathrm{ug} / \mathrm{ml}$, and were grown at $37^{\circ} \mathrm{C}$ for $18 \mathrm{hrs}$.

\section{DNA isolation and purification}

DNA, cut with 2 restriction endonucleases, was separated in $1 \%$ agarose gel and column-purified with commercial kit (Thermo Scientific). The colonies on agar plates have been put into LB medium containing an appropriate antibiotic and were grown until late log phase. Minipreparation of plasmid DNA from $5 \mathrm{ml}$ growth medium was performed by a non-ionic detergent method [19]. Maxipreparation of plasmid DNA from $200 \mathrm{ml}$ growth medium was done by an alkaline lysis method [20]. The plasmid DNA purification for sequencing was done on silica-based columns (Thermo Scientific). The plasmid DNA purification for transfection was done using a non-ionic detergent solution with $\mathrm{LiCl}$ [21]. DNA purity and concentration were measured on Nanodrop 2000 
(Thermo Scientific). The derived genetic constructions were sequence-verified.

\section{Cell culture and transfection}

293T cells were grown until $90 \%$ confluency in DMEM complete at $37^{\circ} \mathrm{C}$ and $5 \% \mathrm{CO}_{2}$ in 6 well plate. For single transfections 2 ug of pECFP-C3$\mathrm{CTTN}$ and $1 \mathrm{ug}$ of pmCitrine-C1-PH were used. For cotransfection 2 ug of pECFP-C3-CTTN and 2 ug of pmCitrineC1-PH were used, and appropriate control vectors pECFP-C3 and pmCitrineC1 were applied in amount of 1 ug each. DNA was diluted in $200 \mathrm{ul}$ of DMEM and appropriate volume of PEI (3:1 ul PEI:ug DNA) was dilluted in 200 ul DMEM. Both solutions were mixed and put on room temperature for $20 \mathrm{~min}$ utes. The transfection mix has been added to the cells covered with the DMEM complete and the cells were grown for $24 \mathrm{hrs}$ at $37^{\circ} \mathrm{C}$ and $5 \% \mathrm{CO}_{2}$. The expression of the target sequences was analysed by regular widefield fluorescent microscopy.

\section{Cell fixation and fluorescent microscopy}

Previous to fixation, the cells were washed twice with PBS prewormed to $37^{\circ} \mathrm{C}(140 \mathrm{mM} \mathrm{NaCl}, 2.7 \mathrm{mM}$ $\mathrm{KCl}, 10 \mathrm{mM} \mathrm{Na} 2 \mathrm{HPO}_{4}, 1.8 \mathrm{mM} \mathrm{KH} \mathrm{PO}_{4}$ ), fixed for 20 minutes in a fixation solution (4\% paraformaldehyde in PBS) at room temperature and washed thrice in PBS. The cells transfected with single constructions were additionally stained with DAPI at concentration of $4 \mathrm{ug} / \mathrm{ml}$. The cell imaging was performed on Leica Microscope. The images were documented by a Canon digital camera and processed in Adobe Photoshop CS5. The DAPI stained cells single- transfected with pECFP-C3-CTTN were imaged in DAPI and FITC filter channels respectively. The DAPI stained cells single- transfected with pmCitrine-C1$\mathrm{PH}$ were imaged in DAPI and Cy3 filter channels respectively and merged with green pseudocoloring of Cy3 channel. The double-transfected cells were imaged in DAPI filter channel for ECFP fluorescence detection and in $\mathrm{Cy} 3$ filter channel for mCitrine fluorescence detection. Merging images of double- transfected cells were done with green pseudocoloring of DAPI channel.

\section{Bioinformatic analysis}

An analysis of putative phosphorylation sites of CTTN by ABL and SRC kinases was performed on GPS 2.1 software [22].

\section{Results and Discussion}

The existence of BCR-ABL fusion protein correlates with the development of some myeloproliferative disorders. However, the exact mechanism of its impact on certain signaling pathways is unknown. Moreover, it is still unclear what provides such differences in a disorder phenotype between the cells that express p190 or p210 proteins. The structural differences are determined by presence or absence of $\mathrm{C} 2, \mathrm{PH}$ and $\mathrm{DH}$ domains, but their direct role is unknown. Interestingly that PH domain is one of the most represented proteome domains and appears 252 times in the human proteome [3, 8]. It has been proposed that binding to phosphatidylinositol-4- and -5-bisphosphate is not the predominant function of $\mathrm{PH}$ domain, and indeed, only $20 \%$ of $\mathrm{PH}$ domains studied possess a strong affinity to this type of phosphoinositides while the rest have weak or no affinity [8]. The fact that many signaling proteins have $\mathrm{PH}$ domain shows it potential role in cellular signaling [23]. In addition, this type of signaling may be followed by the membrane and cytoskeleton remodeling [10]. The previous data indicate that $\mathrm{PH}$ domain often appears in tandem with $\mathrm{DH}$ domain, which may be seen in the BCR protein [24]. DH domain is necessary for the guanine nucleotide exchange factor (GEF) activity. The physiological relevance of this tandem has been studied earlier [25]. For instance, it was demonstrated that $\mathrm{PH}$ domain alone does not always localize in a cellular membrane in contrast to the case where it is in tandem with $\mathrm{PH}$ domain, and that $\mathrm{PH}$ domain alone possesses a low affinity to phosphatidylinositol-4,5-bisphosphate when compared to DHPH tandem [26]. Moreover, binding to plasma membrane seems to be necessary for the conformational changes that promote access for small GTPases and their targets to DH domain $[27,28]$. On the other hand, the full length proteins with these domains often localize on a plasma mem- 

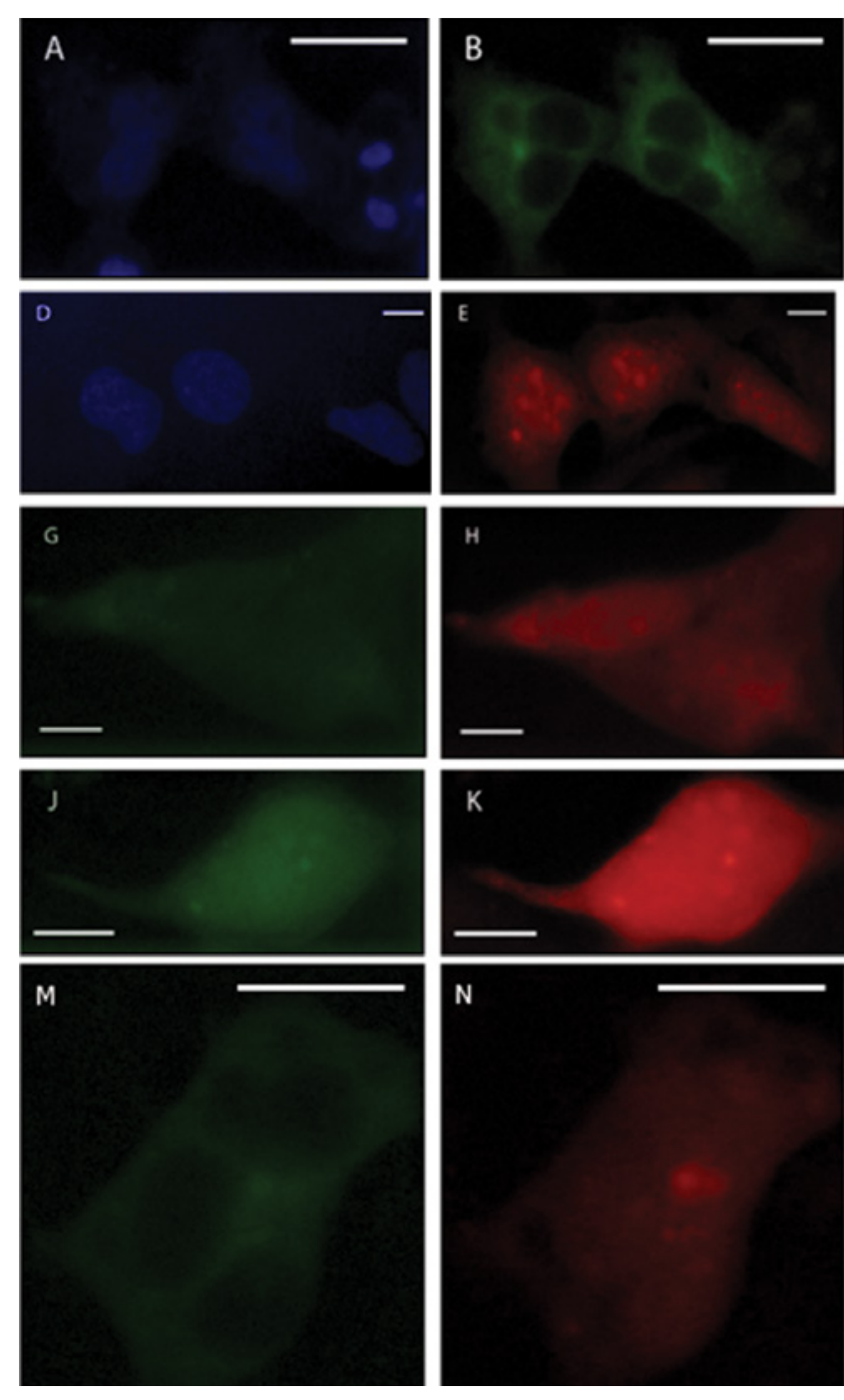

brane. This shows that specific interactions between other multiply domains of BCR are required for membrane anchoring. In this study we demonstrated that $\mathrm{PH}$ domain of $\mathrm{BCR}$ is within the cell nucleus (Fig 1,F). This is consistent with the earlier data of Miroshnychenko et al. [11] and is quite surprising because the full length BCR does not localize within the cell nucleus.

Such interactions may also affect the binding partners of $\mathrm{PH}$ domain. One of the possible binding partners of $\mathrm{PH}$ domain of BCR is cortactin. This protein is overexpressed in many types of cancer [29]. However, in most cases this is true for solid
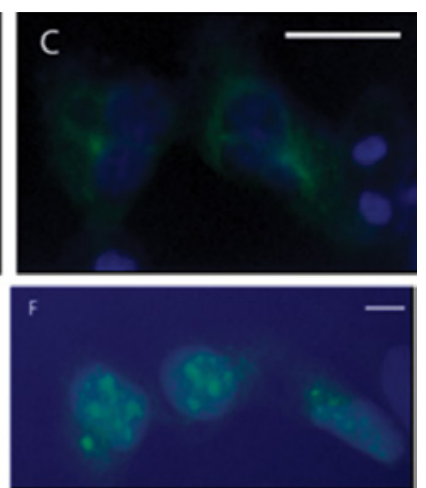

Fig. 1. Expression of target proteins in HEK293T cells after transfection with appropriate vectors. Single transfection with pECFP-C3-CTTN: $A$ - DAPI channel, $B$ - ECFP
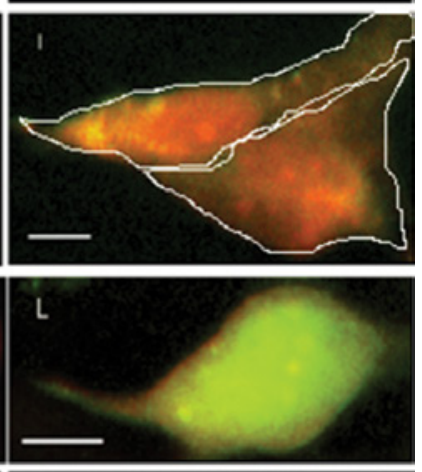
channel, $C-$ merged $\mathrm{A}$ and $\mathrm{B}$; single transfection with pmCitrine-C1-PH: $D$ - DAPI channel, $E$ - mCitrine channel, $F-$ merged $\mathrm{D}$ and $\mathrm{E}$; double transfection with pmCitrinePH and pECFP-C3: $G$ - ECFP channel, $H-\mathrm{mCi}-$ trine channel, $I$-merged $\mathrm{G}$ and $\mathrm{H}$; double transfection with pECFP-C3-CTTN and pmCitrine-C1: $J-$ ECFP $\circ \quad$ channel, $K-$ mCitrine channel, $L$ - merged $\mathrm{J}$ and $\mathrm{K}$; double transfection with $\mathrm{pECFP}$ C3-CTTN and pmCitrine-C1PH: $M-$ ECFP channel, $N-$ mCitrine channel, $O$ - merged $\mathrm{M}$ and $\mathrm{N}$. The scale bar indicates $10 \mu \mathrm{m}$. Cells in I image were outlined for approximate estimation of cell borders and shape. tumors as cortactin is responsible for the cellular invasiveness through the cortical actin branching [30]. The normal function of cortactin is the branching of actin during endocytosis, specifically during scission of clathrine-coated pits [13]. Several factors are required for the cortactin function: phosphorylation by Src kinase, interaction with Arp2/3 complex, and interaction with dynamin. Interestingly that dynamin contains $\mathrm{PH}$ domain but there is no evidence that it interacts with cortactin directly [12]. In terms of protein localization the data about cortactin are rather contradictory. Being localized either on plasma membrane or Golgi com- 

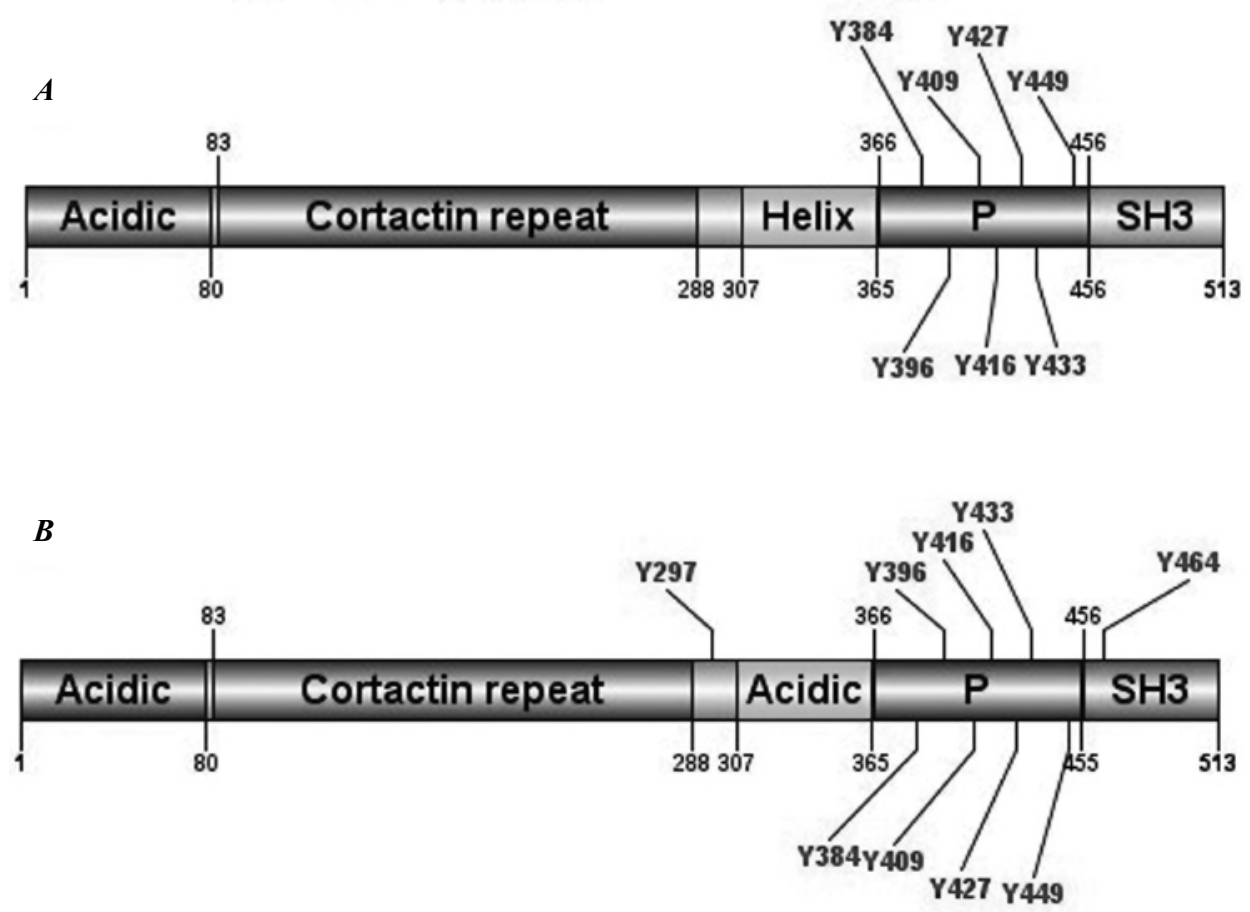

Fig. 2. Phosphorylation sites of cortactin by Abl kinase predicted in GPS 2.1 software. $A$ - prediction for ABL kinase, $B$ - prediction for SRC kinase. Image was generated with DOG plugin of GPS software.

plex this protein affects the Golgi morphology and the post-Golgi transport $[13,31]$. It is worth mentioning that the Golgi complex is rich for phosphatidylinositol-4- and -5-bisphosphates and phosphatidylinositol-4-monophosphate that also possibly may be a target for the $\mathrm{PH}$ domain binding $[32,33]$. An additional evidence of this is that GLG1 protein is among 23 possible protein interactants with $\mathrm{PH}$ domain of BCR showing location on the Golgi cisternae [11]. In the current study we expressed ECFP-fused CTTN in HEK293T cells where it localizes in the dot-like structures and no significant colocalization with a plasma membrane was seen (Fig 1, C, M). This may indicate that CTTN colocalizes with the Golgi complex, although this finding is required verification. When coexpressed with $\mathrm{PH}$ domain, a typical picture of its colocalization with CTTN was observed at specific dot-like regions (Fig 1, O). This colocalization was statistically significant when analysed on the confocal images of identical cells using Pearson correlation coefficient and Manders overlap coefficients comparing to the control samples (unpublished data).
We propose, that this may be perinuclear region or some structures involved in the processes that both PH domain and cortactin normally take part. These findings could shed light on the role of cortactin and $\mathrm{PH}$ domain in the BCR/ABL-induced oncogenesis. Cortactin is activated upon phosphorylation of its proline-rich region by SRC kinase. Therefore, we performed in silico prediction of possible phosphorylation sites of ABL kinase in the protein sequence of cortactin and compared it with predicted sites for SRC kinase. The predicted sites are Y384, Y396, Y409, Y416, Y427, Y433, and Y449 for ABL kinase (Fig. 2, $A$ ) and Y297, Y384, Y396, Y409, Y416, Y427, Y433, Y449, Y464 for SRC kinase (Fig. 2, B).

The prediction shows that 7 sites are identical for both Abl and Src kinase and all of them are within the range of proline-rich region. Interestingly that one site predicted in the proline-rich region (Y384) was experimentally demonstrated to take part in cortactin activation [34]. These results need to be validated experimentally, but are still a good starting point for further studies on mechanisms of 
the cortactin activation by BCR-ABL. Another possible implementation that may have colocalization of cortactin and $\mathrm{PH}$ domain is involment in endocytosis.

Taken together, cortactin is important in the membrane and cytoskeletal remodeling that occurs during endocytosis and vesicular transport, while a characteristic function of $\mathrm{PH}$ domain is to bind membranes rich in phosphatidylinositol-3-phosphate, phosphatidylinositol-4-phosphate and phosphatidylinositol-5-phosphate. Their colocalization may be functionally important for the regulation of cellular signaling dependent on the vesicular transport. Further study would be focused on the experimental validation of the cortactin phosphorylation by ABL kinase predicted in silico, the direct interaction between cortactin and $\mathrm{PH}$ domain. We also need to determine which cellular structures are involved in the overlay of CTTN and PH domain of BCR that has been demonstrated in this work.

\section{Conclusions}

Cortactin has 7 predicted phosphorylation sites for ABL kinase and they are all match with corresponded predicted sites for SRC kinase. On the basis of the previous data, it has been shown that phosphorylation of the proline-rich region of cortactin by Src kinase leads to its activation but not suppression. Therefore it is possible that phosphorylation of the same sites by ABL kinase will lead to the same outcome. However this indeed will be the case of further experimental research of possible phosphorylation of cortactin by BCR-ABL. Cortactin is expressed in cytoplasm only and concentrated in dotlike compartments around the nucleus. PH domain of BCR has both nuclear and cytoplasmic localization but is predominantly localized within the cell nucleus. Cortactin and PH domain of BCR are partially colocalized in the dense perinuclear dot-like regions, which correspondence to the specific cellular structures is yet to be identified in a future research. These findings are a starting point for the investigation of the role of BCR-ABL in the protein sorting and endocytosis.

\section{REFERENCES}

1. Hecht F, Morgan R, Schrier SL, Adams J, Sandberg AA. The Philadelphia $(\mathrm{Ph})$ chromosome in leukemia. I. A new mechanism due to interstitial deletion and insertion in chronic myelocytic leukemia. Cancer Genet Cytogenet. 1985;14(1-2):3-10.

2. Telegeev GD, Dubrovska AN, Dybkov MV, Maliuta SS. Influence of BCR/ABL fusion proteins on the course of $\mathrm{Ph}$ leukemias. Acta Biochim Pol. 2004;51(3):845-9.

3. Telegeev GD, Dybkov MV, Dubrovska AN, Miroshnichenko DA, Tyutyunnykova AP, Maliuta SS. Development of molecular oncohematology in Ukraine. Biopolym Cell. 2013; 29(4): 277-82.

4. Wetzler M, Talpaz M, Van Etten RA, Hirsh-Ginsberg C, Beran $M$, Kurzrock $R$. Subcellular localization of Bcr, Abl, and Bcr-Abl proteins in normal and leukemic cells and correlation of expression with myeloid differentiation. J Clin Invest. 1993;92(4):1925-39.

5. Pane F, Intrieri M, Quintarelli C, Izzo B, Muccioli GC, Salvatore $F$. BCR/ABL genes and leukemic phenotype: from molecular mechanisms to clinical correlations. Oncogene. 2002;21(56):8652-67.

6. Cerione RA, Zheng $Y$. The Dbl family of oncogenes. Curr Opin Cell Biol. 1996;8(2):216-22.

7. Aghazadeh B, Zhu K, Kubiseski TJ, Liu GA, Pawson T, Zheng Y, Rosen $M K$. Structure and mutagenesis of the Dbl homology domain. Nat Struct Biol. 1998;5(12):1098-107.

8. Lemmon MA. Pleckstrin homology domains: not just for phosphoinositides. Biochem Soc Trans. 2004;32(Pt 5):707-11.

9. Lemmon MA, Ferguson KM. Signal-dependent membrane targeting by pleckstrin homology $(\mathrm{PH})$ domains. Biochem J. 2000;350 Pt 1:1-18.

10. Lemmon MA, Ferguson KM, Abrams CS. Pleckstrin homology domains and the cytoskeleton. FEBS Lett. 2002;513(1):71-6.

11. Miroshnychenko D, Dubrovska A, Maliuta S, Telegeev $G$, Aspenström $P$. Novel role of pleckstrin homology domain of the Bcr-Abl protein: analysis of protein-protein and proteinlipid interactions. Exp Cell Res. 2010;316(4):530-42.

12. Zhu J, Zhou K, Hao JJ, Liu J, Smith N, Zhan X. Regulation of cortactin/dynamin interaction by actin polymerization during the fission of clathrin-coated pits. J Cell Sci. 2005;118(Pt 4):807-17.

13. Cao H, Orth JD, Chen J, Weller SG, Heuser JE, McNiven $M A$. Cortactin is a component of clathrin-coated pits and participates in receptor-mediated endocytosis. Mol Cell Biol. 2003;23(6):2162-70.

14. Kirkbride KC, Hong NH, French CL, Clark ES, Jerome WG, Weaver $A M$. Regulation of late endosomal/lysosomal maturation and trafficking by cortactin affects Golgi morphology. Cytoskeleton (Hoboken). 2012;69(9):625-43.

15. Tehrani S, Tomasevic N, Weed S, Sakowicz R, Cooper JA. Src phosphorylation of cortactin enhances actin assembly. Proc Natl Acad Sci U S A. 2007;104(29):11933-8. 
16. Head JA, Jiang D, Li M, Zorn LJ, Schaefer EM, Parsons JT, Weed $S A$. Cortactin tyrosine phosphorylation requires Rac1 activity and association with the cortical actin cytoskeleton. Mol Biol Cell. 2003;14(8):3216-29.

17. Webb BA, Zhou S, Eves R, Shen L, Jia L, Mak AS. Phosphorylation of cortactin by p21-activated kinase. Arch Biochem Biophys. 2006;456(2):183-93.

18. Boyle SN, Michaud GA, Schweitzer B, Predki PF, Koleske AJ. A critical role for cortactin phosphorylation by Abl-family kinases in PDGF-induced dorsal-wave formation. Curr Biol. 2007;17(5):445-51.

19. Lezin G, Kosaka Y, Yost HJ, Kuehn MR, Brunelli L. A onestep miniprep for the isolation of plasmid DNA and lambda phage particles. PLoS One. 2011;6(8):e23457.

20. Birnboim HC, Doly J. A rapid alkaline extraction procedure for screening recombinant plasmid DNA. Nucleic Acids Res. 1979;7(6):1513-23.

21. Lezin G, Kuehn MR, Brunelli L. Hofmeister series salts enhance purification of plasmid DNA by non-ionic detergents. Biotechnol Bioeng. 2011;108(8):1872-82.

22. Xue Y, Liu Z, Cao J, Ma Q, Gao X, Wang Q, Jin C, Zhou Y, Wen L, Ren J. GPS 2.1: enhanced prediction of kinase-specific phosphorylation sites with an algorithm of motif length selection. Protein Eng Des Sel. 2011;24(3):255-60.

23. Ingley $E$, Hemmings $B A$. Pleckstrin homology $(\mathrm{PH})$ domains in signal transduction. $J$ Cell Biochem. 1994;56(4):436-43.

24. Viaud J, Gaits-Iacovoni F, Payrastre B. Regulation of the $\mathrm{DH}-\mathrm{PH}$ tandem of guanine nucleotide exchange factor for Rho GTPases by phosphoinositides. Adv Biol Regul. 2012;52(2):303-14.

25. Zheng $Y$, Zangrilli D, Cerione RA, Eva A. The pleckstrin homology domain mediates transformation by oncogenic dbl through specific intracellular targeting. J Biol Chem. 1996;271(32):19017-20.

26. Baumeister MA, Rossman KL, Sondek J, Lemmon MA. The $\mathrm{Dbs} \mathrm{PH}$ domain contributes independently to membrane targeting and regulation of guanine nucleotide-exchange activity. Biochem J. 2006;400(3):563-72.

27. Worthylake DK, Rossman KL, Sondek J. Crystal structure of the DH/PH fragment of Dbs without bound GTPase. Structure. 2004;12(6):1078-86.

28. Chhatriwala MK, Betts L, Worthylake DK, Sondek J. The $\mathrm{DH}$ and $\mathrm{PH}$ domains of Trio coordinately engage Rho GTPases for their efficient activation. $J$ Mol Biol. 2007;368(5):1307-20.

29. Clark ES, Whigham AS, Yarbrough WG, Weaver AM. Cortactin is an essential regulator of matrix metalloproteinase secretion and extracellular matrix degradation in invadopodia. Cancer Res. 2007;67(9):4227-35.

30. Weaver AM. Cortactin in tumor invasiveness. Cancer Lett. 2008;265(2):157-66.

31. Cao H, Weller S, Orth JD, Chen J, Huang B, Chen JL, Stamnes M, McNiven MA. Actin and Arf1-dependent re- cruitment of a cortactin-dynamin complex to the Golgi regulates post-Golgi transport. Nat Cell Biol. 2005;7(5):483-92.

32. Levine TP, Munro S. The pleckstrin homology domain of oxysterol-binding protein recognises a determinant specific to Golgi membranes. Curr Biol. 1998;8(13):729-39.

33. Levine TP, Munro $S$. Targeting of Golgi-specific pleckstrin homology domains involves both PtdIns 4-kinase-dependent and -independent components. Curr Biol. 2002;12(9):695704.

34. Oser M, Mader CC, Gil-Henn H, Magalhaes M, BravoCordero JJ, Koleske AJ, Condeelis J. Specific tyrosine phosphorylation sites on cortactin regulate Nck1-dependent actin polymerization in invadopodia. J Cell Sci. 2010;123(Pt 21):3662-73.

\section{Колокалізація кортактину і домена РН білка BCR в клітинах НЕК293Т і їі можлива роль у клітинному сигналінгу.}

Д. С. Гур'янов, С. В. Антоненко, Г. Д. Телегеев

Хромосомна транслокація $\mathrm{t}(9 ; 22)(\mathrm{q} 34 ; \mathrm{q} 11)$, яка призводить до утворення трьох різних форм химерного білка BCR-ABL, призводить до виникнення різних форм лейкемій. Вони відрізняються наявністю або відсутністю певних доменів - С2, PH i DH. Мас-спектрометричний аналіз ідентифікував 23 потенційних кандидати на взаємодію з доменом PH BCR. Серед них білок кортактин (CTTN) - мультидоменний білок, що бере участь в розгалуженні актину під час ендоцитозу. Активація корт актину здійснюється за рахунок фосфорилювання кіназою SRC. Однак невідомо, чи здатна ABL кіназа фосфорилювати та активувати CTTN схожим чином. Мета. Показати наявність або відсутність колокалізації між CTTN та доменом PH BCR, передбачити наявність сайтів фосфорилювання ABL кіназою в послідовності CTTN та порівняти ці сайти 3 передбаченими для SRC кінази. Методи. Клітини HЕК293Т були трансфековані створеними конструкціями pECFP-C3-CTTN i pmCitrine-C1-PН за допомогою катіонних полімерів. Можливі сайти фосфорилювання CTTN ABL кіназою були ідентифіковані програмою GPS 2.1. Результати. Експресія домену РН і CTTN в клітинах 293Т показує їх специфічне внутрішньоклітинне розташування. Сайти фосфорилюваня ABL кіназою (Y384, Y396, Y409, Y416, Y427, Y433, and Y449) були знайдені в багатій на пролін ділянці CTTN і співпадають 3 сайтами, передбаченими для SRC кінази. Висновки. Показано, що CTTN має цитоплазматичну локалізацію, в домен РН локалізований переважно в ядрі, але присутній і в цитоплазмі. Вони частково колокалізовани в специфічних точкових навколоядерних ділянках. Можливе фосфорилювання CTTN ABL кіназою може бути одним із шляхів активації під час лейкемогенезу.

Кл юч о в і сл о в а: XMЛ, BCR-ABL, домен PH, CTTN. 


\section{Колокализация кортактина и домена PH белка BCR в клетках НЕК293Т и ее возможная роль в клеточном сигналинге.}

\section{Д. С. Гурьянов, С. В. Антоненко, Г. Д. Телегеев}

Хромосомная транслокация $\mathrm{t}(9 ; 22)(\mathrm{q} 34 ; \mathrm{q} 11)$, ведущая к образованию трех разных форм химерного белка BCR-ABL, приводит к возникновению разных типов лейкемий. Они отличаются наличием или отсутствием определенных доменов - C2, домены гомологии плекстрина (PH) и гомологии $\mathrm{Dbl}(\mathrm{DH})$. Масс-спектрометрический анализ идентифицировал 23 потенциальных кандидат на взаимодействие с PH доменом BCR. Среди них белок кортактин (CTTN) - мультидоменный белок, берущий участие в разветвлении актина во время ендоцитоза. киназой в последовательности CTTN, а также сравнить эти сайты с таковыми Активация кортактина осуществляется за счет его фосфорилирования киназой SRC. Однако не известно, может ли ABL киназа фосфорилировать кортактин и активировать его таким же образом. Цель. показать наличие или отсутствие колокализации между CTTN и доменом PH BCR, предсказать наличие сайтов фосфорилирования
ABL для SRC киназы. Методы. Клетки HEK293Т были трансфецированы созданными конструкциями рЕСFР-С3CTTN и pmCitrine-C1-PH с помощью катионных полимеров. Возможные сайты фосфорилирования CTTN ABL киназой были идентифицированы программой GPS 2.1. Результаты. Экспрессия домена РН и CTTN в клетках 293Т показывает их специфическое внутриклеточное расположение. Сайты фосфорилирования ABL киназой (Y384, Y396, Y409, Y416, Y427, Y433, and Y449) были найдены в богатом пролином участке CTTN и они совпадают с предсказанными сайтами фосфорилирования для SRC киназы. Выводы. Показано, что CTTN имеет цитоплазматическую локализацию, а домен РН локализирован преимущественно в ядре, но присутствует и в цитоплазме. Они частично колокализованы в специфических точкообразных околоядерных участках. Возможное фосфорилирование CTTN ABL киназой может быть одним из путей активации во время лейкемогенеза.

Кл юч е в ы е л о в а: XMЛ, BCR-ABL, домен PH, CTTN.

Received 22.01.2015 